Case Report

\title{
A Case of Recurrent Renal Aluminum Hydroxide Stone
}

\author{
Basri Cakuroglu, ${ }^{1}$ Akif Nuri Dogan, ${ }^{2}$ Tuncay Tas, ${ }^{3}$ \\ Ramazan Gozukucuk, ${ }^{4}$ and Bekir Sami Uyanik ${ }^{5}$ \\ ${ }^{1}$ Hisar Intercontinental Hospital, Department of Urology, Umraniye, 34768 Istanbul, Turkey \\ ${ }^{2}$ Hisar Intercontinental Hospital, Department of Internal Medicine, Umraniye, 34768 Istanbul, Turkey \\ ${ }^{3}$ Taksim Training and Research Hospital, Department of Urology, Taksim, 34433 Istanbul, Turkey \\ ${ }^{4}$ Hisar Intercontinental Hospital, Department of Infectious Diseases and Clinical Microbiology, Umraniye, 34768 Istanbul, Turkey \\ ${ }^{5}$ Hisar Intercontinental Hospital, Department of Clinical Biochemistry, Umraniye, 34768 Istanbul, Turkey
}

Correspondence should be addressed to Basri Cakıroglu; drbasri@gmail.com

Received 19 February 2014; Accepted 29 April 2014; Published 9 June 2014

Academic Editor: Francesco M. Solivetti

Copyright (c) 2014 Basri Cakıroglu et al. This is an open access article distributed under the Creative Commons Attribution License, which permits unrestricted use, distribution, and reproduction in any medium, provided the original work is properly cited.

Renal stone disease is characterized by the differences depending on the age, gender, and the geographic location of the patients. Seventy-five percent of the renal stone components is the calcium $(\mathrm{Ca})$. The most common type of the stones is the Ca oxalate stones, while Ca phosphate, uric acid, struvite, and sistine stones are more rarely reported. Other than these types, triamterene, adenosine, silica, indinavir, and ephedrine stones are also reported in the literature as case reports. However, to the best of our knowledge, aluminum hydroxide stones was not reported reported before. Herein we will report a 38-years-old woman with the history of recurrent renal colic disease whose renal stone was determined as aluminum hydroxide stone in type. Aluminum mineral may be considered in the formation of kidney stones as it is widely used in the field of healthcare and cosmetics.

\section{Background}

The estimated lifetime prevalence of kidney stone disease is $1-15 \%$. The probability of having a urinary stone differs according to age, gender, race, and geographic location of the patients. It has been determined that men are affected by stone disease two to three times more commonly than women in adulthood [1].

The most common type of the stones is the calcium oxalate $\mathrm{CaOx}$ type which makes up the $60 \%$ of all. It is followed by mixed calcium oxalate and hydroxyapatite stones establishing $20 \%$ of renal calculi. Calcium, being the major component of approximately $75 \%$ of stones, is the most common constituent of urinary calculi. The other reported stones are uric acid and struvite (magnesium ammonium phosphate) stones occurring in $10 \%$ of cases and brushite stones with an incidence of $2 \%$ in all stones and rarely reported (1\%) cysteine stones. On the other hand, some stones associated with medications and their by-products are also reported including triamterene, adenosine, silica, indinavir, and ephedrine [2].
For a long time, essential and toxic trace elements have been suggested to play a role in urinary stone formation. In this topic, it was also recommended to accomplish studies on some trace elements including aluminum or lead [3].

Aluminum is the normal component of raw water and its concentrations are determined to be high in surface waters while it is usually low in amount in ground waters [4]. Aluminum toxicity is an uncommon condition and almost always reported in iatrogenic cases including patients receiving total parenteral nutrition and dialysis patients using aluminum-containing phosphate binders, antacids, and dialysates [5].

Herein we will report a patient with urinary stone containing high aluminum hydroxide component, which is not reported before in the literature.

\section{Case Report}

Thirty-eight-year-old woman with $162 \mathrm{~cm}$ height and $76 \mathrm{~kg}$ weight was admitted to our outpatient clinic with the complaint of renal colic. She had a history of renal stone 
TABLE 1: Metabolic investigations in serum and 24-hour urinary excretion.

\begin{tabular}{|c|c|c|c|c|}
\hline & \multicolumn{2}{|c|}{ Serum } & \multicolumn{2}{|c|}{$\begin{array}{l}\text { Urine (24 Hours) } \\
\text { Volume: } 1700 \mathrm{~mL}\end{array}$} \\
\hline & Result & Reference range & Result & Reference range \\
\hline Density & - & - & 1020 & $1010-1025$ \\
\hline $\mathrm{pH}$ & - & - & 6.5 & $4.5-7.5$ \\
\hline Creatinine & $0.55 \mathrm{mg} / \mathrm{dL}$ & $0.51-1.05$ & $1.31 \mathrm{~g} / \mathrm{day}$ & $0.6-1.6$ \\
\hline Aluminum & $32 \mu \mathrm{g} / \mathrm{L}$ & $1-14$ & $3.67 \mu \mathrm{g} /$ day & $<50$ \\
\hline Oxalate & - & - & $33 \mathrm{mg} /$ day & $<45$ \\
\hline Citrate & - & - & 1132 mg/day & $252-1164$ \\
\hline Calcium & $9.87 \mathrm{mg} / \mathrm{dL}$ & $8.8-10.2$ & $0.38 \mathrm{~g} / \mathrm{day}$ & $0.1-0.3$ \\
\hline Phosphorus & $3.32 \mathrm{mg} / \mathrm{dL}$ & $2.7-4.5$ & $0.65 \mathrm{~g} / \mathrm{day}$ & $0.40-1.3$ \\
\hline Magnesium & $1.9 \mathrm{mg} / \mathrm{dL}$ & $1.58-2.55$ & $0.080 \mathrm{~g} /$ day & $0.060-2$ \\
\hline Sodium & $136 \mathrm{mEq} / \mathrm{L}$ & $135-145$ & $160 \mathrm{mEq} /$ day & $40-220$ \\
\hline Potassium & $3.6 \mathrm{mEq} / \mathrm{L}$ & $3.5-5.5$ & $56 \mathrm{mEq} /$ day & $25-125$ \\
\hline Parathormone & $57 \mathrm{pg} / \mathrm{mL}$ & $15-68$ & - & - \\
\hline Alkaline phosphatase & $100 \mathrm{IU} / \mathrm{L}$ & $35-104$ & - & - \\
\hline Gamma glutamyl transferase & $30 \mathrm{IU} / \mathrm{L}$ & $7-40$ & - & - \\
\hline
\end{tabular}

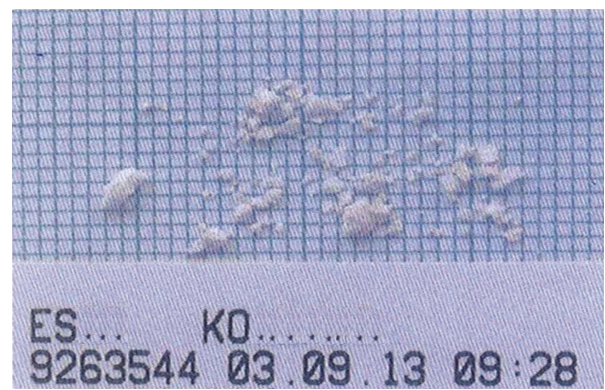

FIGURE 1: Four of stones broken by hand.

diseases for 6 times in the last 6 months with 20-40 days of intermittences. Her stones were white in color and they were easily dispersible with a diameter of $3-5 \mathrm{~mm}$ approximately (Figure 1). She had collected her stones and Fourier transform infrared spectroscopy (FTIR) was performed to the stones for the analysis (Figure 2). The results of the analysis revealed that $45.1 \%$ of the stones were aluminum hydroxide and $44.9 \%$ were carbonate apatite and protein. Metabolic investigations were made both in serum and 24-hour urine in order to determine the etiology of stone (Table 1). Serum aluminum was determined as $32 \mu \mathrm{g} / \mathrm{L}(1-14)$ and calcium was $9.87 \mathrm{mg} / \mathrm{dL}$ (8.8-10.2), while urinary calcium excretion was $0.38 \mathrm{~g} /$ day (0.1-0.3). In her history it was determined that she was using a roll-on deodorant that was containing aluminum. After 2-month period of dismissing this deodorant, her serum aluminum level was $12 \mu \mathrm{g} / \mathrm{L}$ (1-14) and her urinary aluminum excretion was in normal limits $(3.67 \mu \mathrm{g} /$ day, reference range: $<50)$.

She was evaluated with urinary ultrasound and tomography for the presence of stone disease and they were all normal. In approximately 5 months of follow-up, she did not have any renal colic attacks.

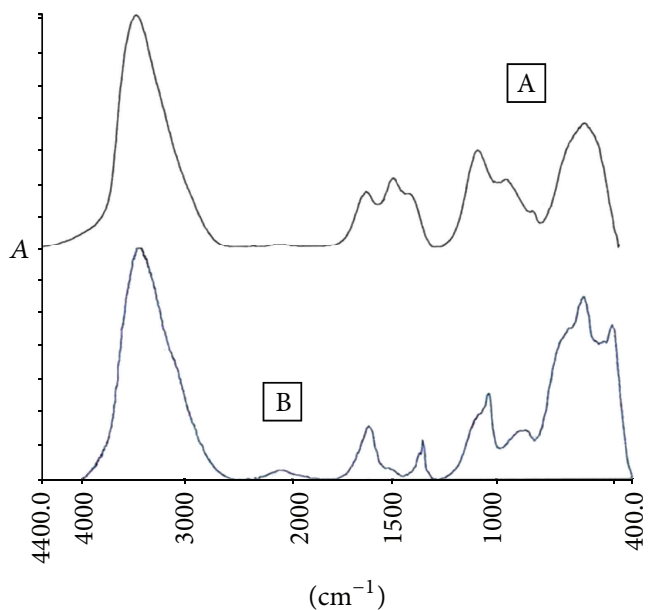

Euclidean Hit List:

0.451 KS0034 0034.SP aluminium hydroxyde

$0.449 \mathrm{KS} 0103$ 0103.SP carbonate apatite 70\% + proteins 30\%

0.399 KS0216 0216.SP protein-alpha chymotrypsin

0.397 KS0362 0362.SP whitlockite 65\% + carbonate apatite 35\%

0.393 KS1010 1010.SP $60 \%$ whitlockite $+40 \%$ protein

FIGURE 2: The analysis of stones (Fourier transform infrared spectroscopy).

\section{Discussion}

To the best of our knowledge, any data about the aluminum hydroxide stones was not present in the literature among urinary stones up to date. Nowadays, the role of essential and trace elements is being discussed in formation of stones. Though in some studies these trace elements were reported to be present in trace amounts in stone mass, these elements were thought to be not present in high concentrations in the structure of stone $[3,6-8]$. 
Aluminum toxicity is a rare disorder that typically occurs iatrogenically in patients receiving total parenteral nutrition and in dialysis patients taking aluminum-containing phosphate binders, antacids, and dialysates [5]. Aluminumcontaining phosphate binders have been used for hyperphosphatemia treatment in dialysis patients for a long time. A cautious follow-up is suggested for dialysis patients using aluminum containing phosphate binders for the increased risk of Al-Mg-urate stone formation.

Inhibitory crystallization deficits and supersaturated levels of different salts, promoters, and inhibitors of crystallization have been determined to play a major role in stone disease formation. In this aspect, the main natural inhibitors of calculi formation are known as citrate, pyrophosphate, nephrocalcin, glycosaminoglycans, magnesium, and zinc [9].

The role of trace elements in urinary stone formation is still unknown and controversial. Durak et al. have studied the distribution of five metals (Iron, copper, cadmium, zinc, and magnesium) in 47 stones and hair of patients and found significant differences among the element levels in stones, patient hair, and control hair [6]. Levinson et al. suggested that some trace elements (such as aluminum and lead) play a role in stone formation and studies about this topic are warranted [3]. In another in vitro study, urinary aluminum was determined to affect the enlargement of calcium oxalate crystals. The writers concluded that though trace elements in calculi did not directly affect the formation of $\mathrm{CaOx}$ and calcium phosphate $(\mathrm{CaP})$ stones in normal conditions, they resulted in urinary stone formation with metabolic processes [8]. Previously, in some studies the stones were analyzed completely and in different stone types, the concentrations of trace elements were determined to be different [4-6]. In some studies, the concentrations of some heavy metals (lead, cadmium, nickel, and aluminum) were found to be higher in nuclear region compared with the crust [7].

Aluminum hydroxide was used for many purposes but currently it is often used in medical antiacid treatment and in cosmetic products as preservative. In our case, aluminum stone was presented in mixed type. There was no history of anti-acid or work-exposure to aluminum in our patient. However she was using a cosmetic material containing aluminum and dismissing this product decreased serum aluminum levels and stone recurrences. In 6-month period after dismissing this cosmetic product, any complaints of renal colic or stone disease were not reported.

\section{Conclusion}

In the literature there is no data about the association of increased renal stone disease risk with medically used aluminum hydroxide in patients other than hemodialysis patients.

Aluminum mineral may be considered in the formation of kidney stones as it is widely used in the field of healthcare and cosmetics. This issue should be discussed and should be clarified by further investigations.

\section{Disclosure}

All the authors deny any meaningful affiliation or involvement, either direct or indirect, with any organization or entity with a direct financial interest in the subject matter or materials and any financial or material support for the work.

\section{Conflict of Interests}

The authors of the paper do not have any direct financial relation with the commercial identities mentioned in the paper that might lead to a conflict of interests.

\section{References}

[1] S. M. Bartosh, "Medical management of pediatric stone disease," Urologic Clinics of North America, vol. 31, no. 3, pp. 575-587, 2004.

[2] D. M. Wilson, "Clinical and laboratory approaches for evaluation of nephrolithiasis," Journal of Urology, vol. 141, no. 3, pp. 770-774, 1989 .

[3] A. A. Levinson, M. Nosal, M. Davidman, E. L. Prien Sr., E. L. Prien Jr., and R. G. Stevenson, "Trace elements in kidney stones from three areas in the United States," Investigative Urology, vol. 15, no. 4, pp. 270-274, 1978.

[4] A. K. Susheela, N. K. Mondal, and A. Singh, "Exposure to fluoride in smelter workers in a primary aluminum industry in India," International Journal of Occupational and Environmental Medicine, vol. 4, no. 2, pp. 61-72, 2013.

[5] J. A. Jaffe, C. Liftman, and J. D. Glickman, "Frequency of elevated serum aluminum levels in adult dialysis patients," The American Journal of Kidney Diseases, vol. 46, no. 2, pp. 316-319, 2005.

[6] I. Durak, Z. Kilic, H. Perk et al., "Iron, copper, cadmium, zinc and magnesium contents of urinary tract stones and hair from men with stone disease," European Urology, vol. 17, no. 3, pp. 243-247, 1990.

[7] H. Perk, T. A. Serel, A. Koşar, N. Deniz, and A. Sayin, "Analysis of the trace element contents of inner nucleus and outer crust parts of urinary calculi," Urologia Internationalis, vol. 68, no. 4, pp. 286-290, 2002.

[8] J. L. Meyer and E. E. Angino, "The role of trace metals in calcium urolithiasis," Investigative Urology, vol. 14, no. 5, pp. 347-350, 1977.

[9] O. W. Moe, "Kidney stones: pathophysiology and medical management," The Lancet, vol. 367, no. 9507, pp. 333-344, 2006. 


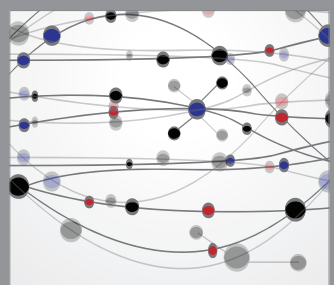

The Scientific World Journal
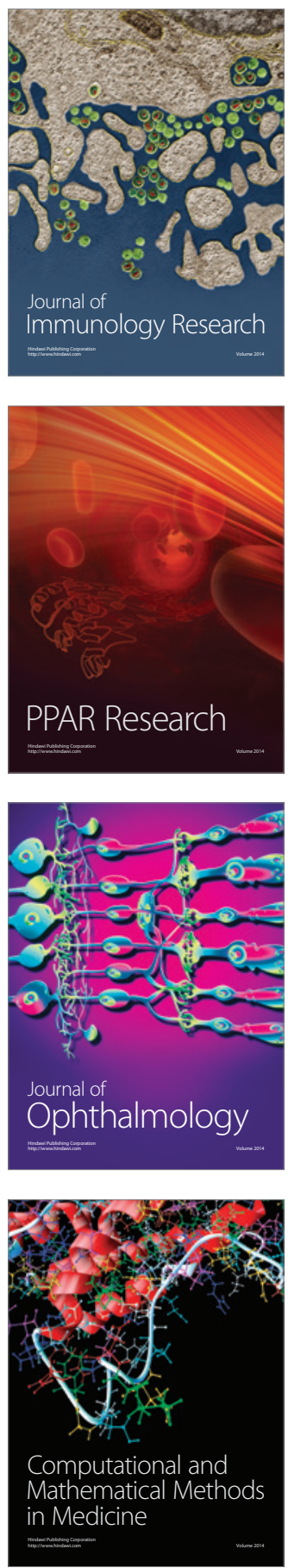

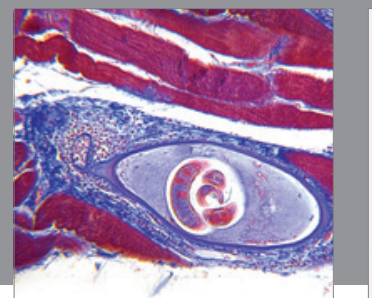

Gastroenterology

Research and Practice
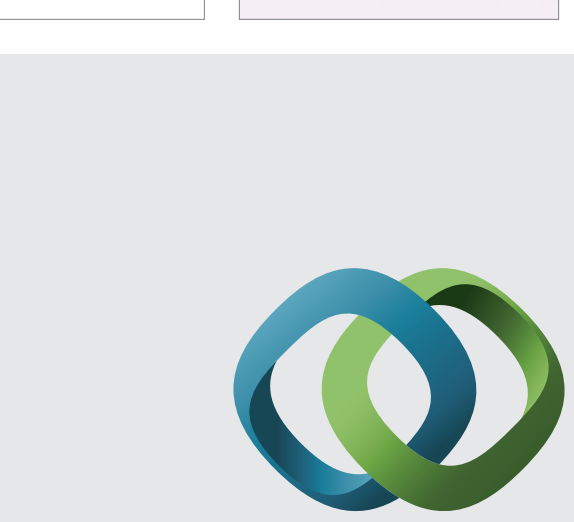

\section{Hindawi}

Submit your manuscripts at

http://www.hindawi.com
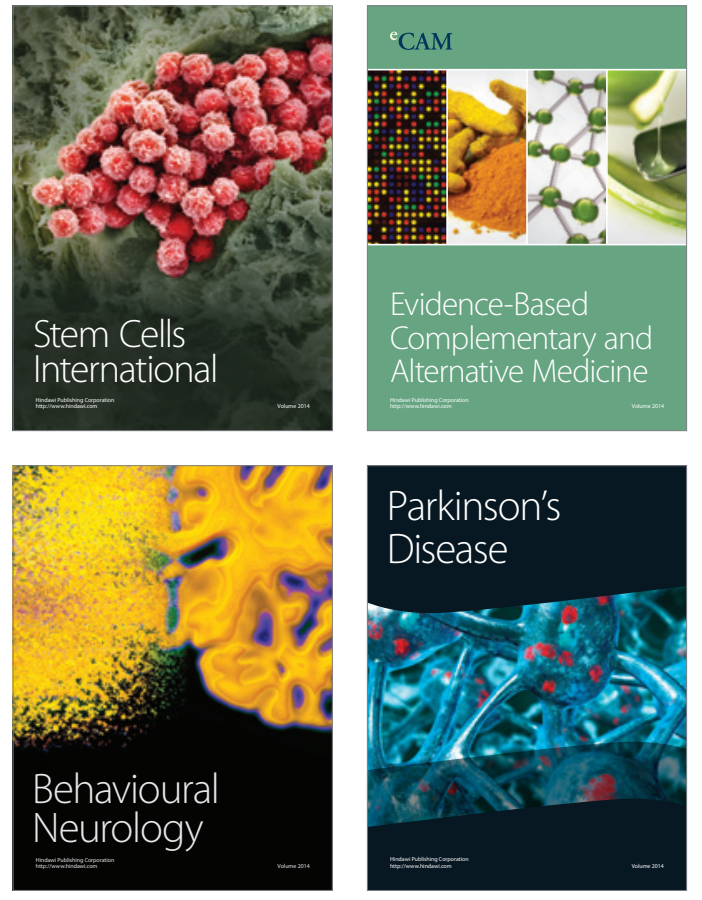
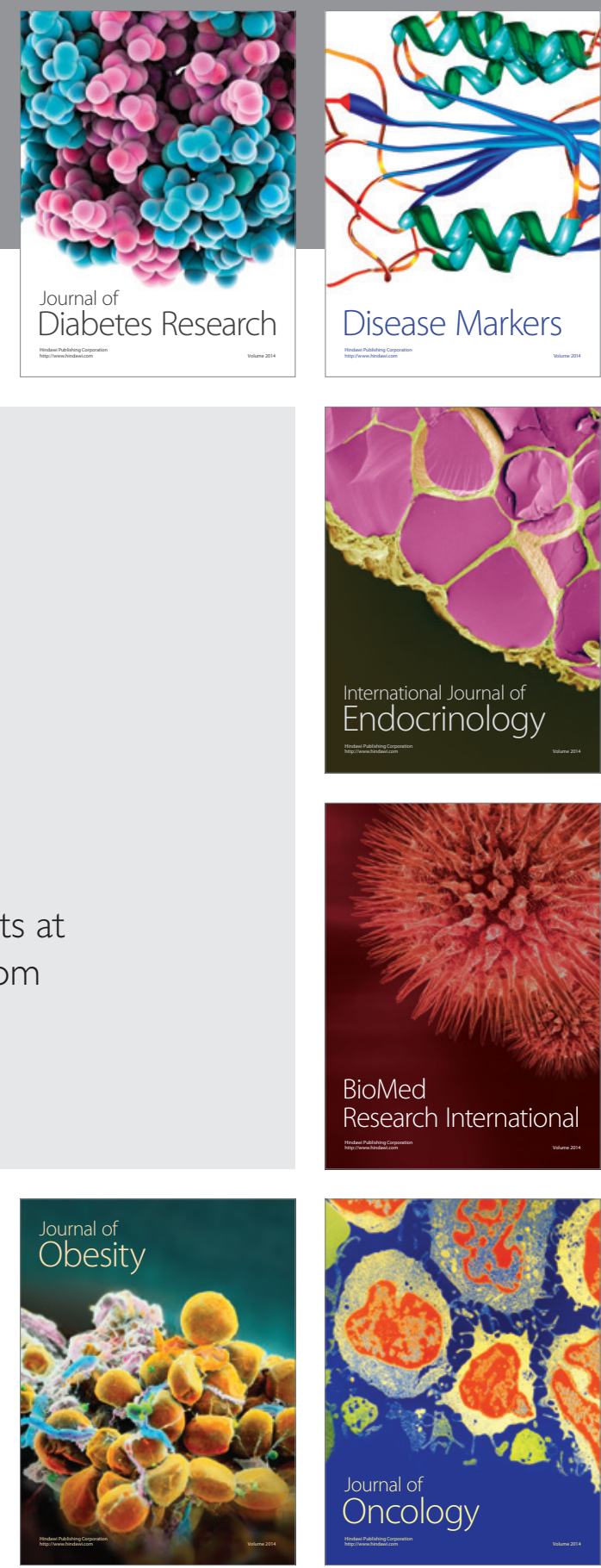

Disease Markers
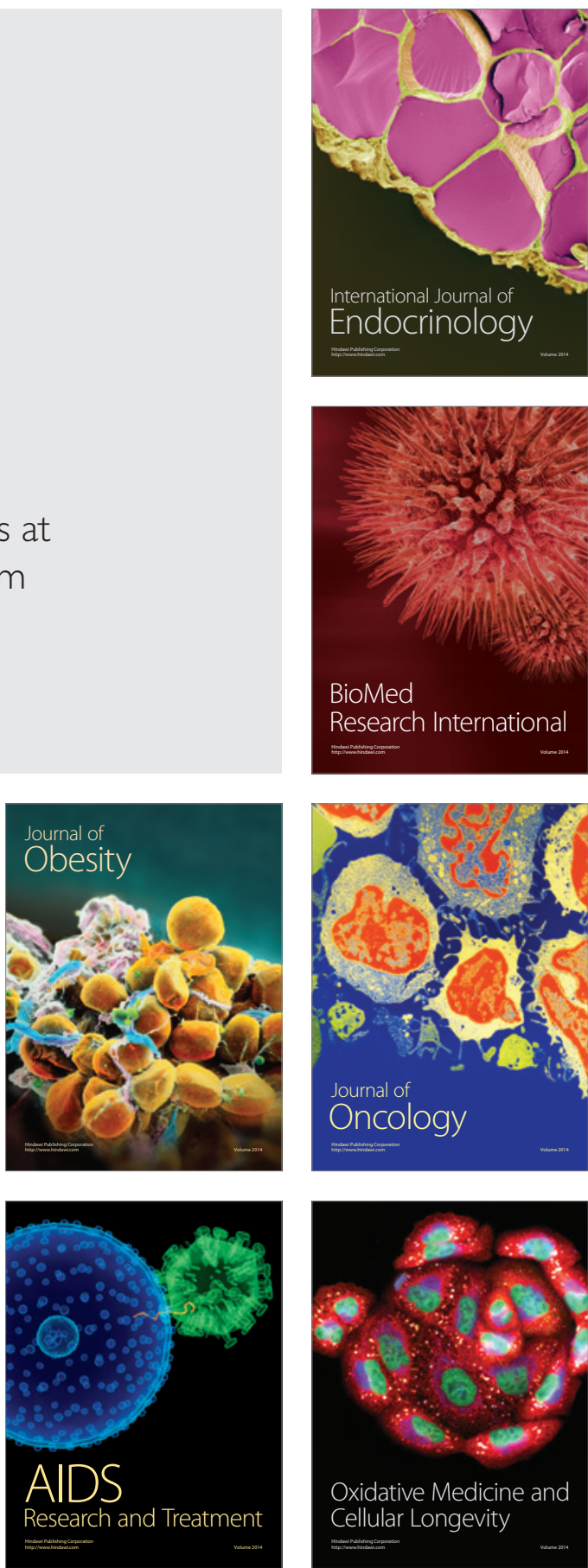